\title{
p53 PROTEIN DETECTED BY IMMUNO- HISTOCHEMICAL STAINING IS NOT ALWAYS MUTANT
}

\author{
CATRIONA MACGEOCH ${ }^{\dagger}$,DIANA M. BARNES ${ }^{\S}$, JULIA A. NEWTON ${ }^{\llbracket}$, SHEHLA MOHAMMED ${ }^{\S}$, \\ SHIRLEY V. HODGSON $\$$, MUN NG ${ }^{\dagger \dagger}$, D. TIMOTHY. BISHOP ${ }^{\ddagger}$ AND NIGEL K. SPURR ${ }^{* \dagger}$ \\ ${ }^{\dagger}$ Human Genetic Resources, Imperial Cancer Research Fund, Clare Hall Laboratories, South Mimms, \\ Potters Bar, Herts. EN6 $3 L D$ \\ \$Imperial Cancer Research Fund, Clinical Oncology Unit, Guy's Hospital, London SE1 9RT \\ IIImperial Cancer Research Fund, Skin Tumour Laboratory, Department of Dermatology, Royal London \\ Hospital, Whitechapel, London El lBB \\ ${ }^{\dagger}$ Department of Microbiology, University of Hong Kong, Pathology Building, Queen Mary Hospital \\ Compound, Pokfulam Road, Hong Kong. \\ $\ddagger$ Imperial Cancer Research Fund, Genetic Epidemiology Laboratory, St. James’s Hospital, Leeds.
}

\begin{abstract}
SUMMARY
The expression of the tumour suppressor gene p53 was analyzed in a variety of human solid tumours by immunohistochemistry and direct DNA sequencing. Positive nuclear staining using a panel of anti-p53 antibodies was used to select tumours for further genetic analysis. Using PCR amplification followed by immobilization onto magnetic beads and direct sequencing, we sequenced exons 5-9 of the p53 gene from 9 melanomas, 8 nasopharyngeal carcinomas, 16 sporadic breast carcinomas and 11 patients from familial breast cancer families. No sequence alterations of the p53 gene were detected in either the melanoma or nasopharyngeal tumours and only $19 \%$ of the primary breast carcinomas showed a variant band indicative of a mutation. Our results indicate firstly that p53 mutations are not generally involved in the tumour types studied and secondly the data emphasize the disparity encountered when attempting to correlate p53 immunohistochemical positivity with mutations within the p53 gene.
\end{abstract}

KEYWORDS p53 Breast cancer Melanoma Nasopharyngeal carcinoma

\section{INTRODUCTION}

The progression of human cancer is associated with multiple genetic changes involving both activation of oncogenes and inactivation of tumour suppressor genes. The most common genetic alteration is now widely accepted to be mutation of the p53 gene on chromosome 17p (Nigro et al., 1989; Hollstein et al., 1991). The normal function of p53 in the cell is thought to be twofold: firstly p53 acts as a tumour suppressor gene in negatively regulating cell growth (Levine, 1991). A mutation within the gene consequently leads to altered p53 protein with loss of suppressor activity. However, this loss of activity can also be triggered by binding of other proteins and recent reports have shown that the transforming oncogene, MDM2, can inactivate the tumour suppressor

*Correspondence to:Dr. N.K. Spurr, Human Genetic Resources, Imperial Cancer Research Fund, Clare Hall Laboratories, South Mimms, Potters Bar, Herts EN6 3LD, U.K. 
activity of p53 by complexing to it (Oliner et al., 1992). Both these processes i.e. mutation and protein binding, interfere with the ability of p53 to bind to DNA in a sequence specific fashion and result in subsequent stabilization of p53 protein. Secondly, p53 is now emerging as a potent transcription factor. Farmer et al,1992, have shown that wild type p53 directly activates transcription but that this activity can be inhibited by the mutant p53. Point mutations abolish this transcriptional function of p53 by altering the folding of the protein. These and other studies show that p53 protein can be stabilized by mechanisms other than a point mutation within the p53 gene (Lane, 1992).

Nearly every tumour type analyzed to date exhibits alterations in the p53 gene. e.g. breast cancer, lung, colon, liver, brain and lymphomas and leukaemias (For reviews see Hollstein et al., 1991; Levine, 1991). These studies have demonstrated that multiple different point mutations are common in the p53 gene. Most have been shown to be missense mutations. Certain domains of p53 are also highly conserved among different species (Soussi et al., 1991) and those domains covering exons 5-8 are frequently the site of mutations. The frequency of mutation however varies in different cancers e.g. from $17 \%$ in breast tumours to over $90 \%$ in colon cancer (Hollstein et al., 1991). It is not known why there is such a wide variation in the mutational spectra between different cancers although certain specific etiological roles have been identified e.g. a G-T specific substitution at codon 249 induced by the liver-specific carcinogen, aflatoxin B 1 (Bressac et al., 1991) and UV induced damage causing a specific CC-TT double base p53 mutation (Brash et al., 1991).

In this study we have analyzed three types of tumours, breast, melanoma and nasopharyngeal. Many reports have now shown the involvement of the p53 gene in sporadic breast tumours. Positive immunohistochemical staining indicative of stabilized p53 is seen in more than of 50\% of tumours (Varley et al., 1991; Davidoff et al., 1991; Barnes et al., 1993). However, the frequency of p53 mutations at the DNA level reported in primary breast tumours is lower ranging from $18 \%$ to $46 \%$ of tumours tested (Osborne et al., 1991; Moll et al., 1992). Constitutional p53 mutations in non Li-Fraumeni early onset breast cancer families appear to be rare and recent reports indicate that familial breast cancer does not usually result from germ-line point mutations in the p53 gene (Warren et al., 1992; Sidransky et al. 1992). Malignant melanoma is primarily thought to arise due to an increased intermittent exposure to relatively high doses of ultraviolet (UV) radiation (Brash et al., 1991). Treatment of cells with DNA damaging agents such as UV light have been shown to increase the stability of the p53 protein, (Maltzman and Czyzyk, 1984) and more recently, Hall et al. (1993) reported high levels of p53 protein accumulation in UV-irradiated normal human skin. Melanoma has been reported to have the highest incidence yet recorded of mutant p53 over expression by virtue of immunohistochemical detection in primary and metastatic melanomas (Stretch et al., 1991; Bartek et al., 1991). Nasopharyngeal carcinoma (NPC) is the third most common cancer in Southern China. NPC is strongly associated with the presence of Epstein-Barr virus and we wished to study the possible role of p53 in the pathogenesis of this disease.

In normal cells, p53 is usually undetectable by immunohistochemical methods due to its short intracellular half life. Mutation of the p53 gene results in stabilization of the protein and a subsequent increase in intracellular protein sufficient to be detectable by immunohistochemistry. Initially, immunohistochemical detection of p53 was taken as good evidence of p53 gene mutation. However, reports of both false positives and false negatives are now common enough to make immunohistochemical positivity a poor 
indicator of an underlying mutation (Wynford-Thomas, 1992). A recent paper on p53 data in sporadic breast cancer (Coles et al., 1992), reviewed the discrepancy between estimates of mutation frequency as performed by DNA analysis (40\%) or immunohistochemistry methods $(60 \%)$. The most informative method for analysis of p53 mutations is to determine the nucleotide sequence as this allows for the unequivocal detection of sequence alterations. As an alternative to SSCP we have developed previously a rapid strategy using PCR and solid phase sequencing in order to detect mutations within the p53 gene (MacGeoch et al., 1991).

In this paper we have identified a number of tumours with different patterns and intensities of immunohistochemical staining for $\mathrm{p} 53$ protein and have correlated these with the presence or absence of p53 DNA mutations.

\section{MATERIALS AND METHODS}

\section{Sample Aquisition}

\section{Breast Cancer; Sporadic Samples}

DNA was isolated from 16 blood and tumour paired samples which were obtained from patients attending the I.C.R.F. Clinical Oncology Unit, Guys Hospital, London. Histological assessment of the tumours was carried out by one pathologist and were typed according to the WHO classification (WHO), 1982) and graded following the criteria of Bloom and Richardson (1957). All the tumours showed positive immunohistochemical reactivity with $\mathrm{p} 53$ protein.

\section{Breast Cancer; Germ-Line Samples}

Genomic DNA from whole blood was also available from an additional 11 women attending the same unit. These patients are all premenopausal women with breast cancer and a family history of malignancies.

\section{Melanoma samples}

Melanoma tumour biopsies were collected by the I.C.R.F. Skin Tumour Laboratory, Royal London Hospital. Tumours were taken at the time of resection, snap frozen and stored at $-80^{\circ} \mathrm{C}$ until DNA extraction. Among the melanomas, 14 were primary tumours and 9 were obtained from metastatic melanomas. Dysplastic or atypical naevus material was available from 5 cases. We also had available to us 9 blood/tumour pairs from patients with primary melanoma some of whom were members of families showing a familial history of melanoma.

\section{Nasopharyngeal tumour samples}

Tumour DNA was obtained from 8 nasopharyngeal carcinoma cases from either Hong Kong or the Guangdong region of Southern China. All patients were Southern Chinese in origin.

\section{DNA Extraction}

DNA was extracted from all blood samples using a modified sodium perchlorate method of Johns and Pauls-Thomas, 1989, as supplied in Nucleon 11 DNA extraction kit from Scotlab, U.K. Tumour DNA was isolated according to standard procedures (Sambrook et al., 1989). 


\section{Immunocytochemistry}

\section{Breast cancer samples}

Staining was carried out using the anti-p53 polyclonal antibody, CM-1, in a peroxidase conjugated streptavidin biotin technique following the method of Midgely et al. (1992). Positive nuclear staining, indicative of the presence of stabilized p53 protein, was used to select tumours for further genetic analysis.

\section{Melanoma samples}

The antibody CM-1 was used to detect $\mathrm{p} 53$ protein in $5 \mu \mathrm{m}$ thick tissue sections which had been fixed in acetone and methanol using the method described above.

\section{Nasopharyngeal tumour samples}

Staining was carried out on 8 NPC tumours using either the monoclonal antibodies pAB 1801 or pAB 240 on frozen tissue sections.

\section{Antibodies}

CM1 is a polyclonal antibody which will recognise both normal and mutant forms of the p53 protein (Midgley et al., 1992). Pab 1801 and Pab 240 are monoclonal antibodies which also recognise both wild type and mutant $\mathrm{p} 53$ protein by immuno histochemistry. CM-1 and Pab 1801 work on tissue that has been well fixed. However, the quality of the staining is very dependent on the type of fixative and the temperature of the fixation process (Fisher et al., 1994).

\section{Controls}

In each assay, sections from a tissue found previously to contain stabilized p53 protein was used as a positive control. A negative control, in which PBS replaced the primary antibody, was also included. Any assay in which either control was considered to be unsatisfactory was repeated.

\section{PCR amplification and sequencing}

Total genomic DNA from the various samples was used in a PCR reaction using primers P3 and P4 as described by Nigro et al. (1989). This PCR product was $2.9 \mathrm{~kb}$ long and included exons 4-9 of the p53 gene. A second round of PCR was performed exon by exon using one of the primers biotinylated at the 5' end. PCR amplification, immobilization onto magnetic beads and sequencing was carried out as previously described (MacGeoch et al., 1991). Briefly, the biotinylated PCR product was bound to magnetic beads, Dynabeads M-280 (Dynal, Oslo, Norway) and after strand separation, sequencing was performed on the resulting single stranded template using the non-biotinylated amplimer as a sequencing primer, [35S]dATP and Sequenase 2.0 (United States Biochemical).

\section{RESULTS}

\section{Immunohistochemical detection of 553 in sporadic breast tumours}

Fifteen of the 16 tumours selected were infiltrating ductal carcinomas (1, grade 11 and 14, grade 111) There was one case of infiltrating lobular carcinoma of a variant pleomorphic type with a high mitotic count. Positive staining was classified according 
to the intensity of the stain (moderate or strong) and to whether some (heterogeneous) or all (homogeneous) of the tumour cells stained. There were seven cases of strong homogeneous staining, six of these were infiltrating ductal grade 111 and one was the lobular variant. The remaining nine cases all showed heterogeneous staining, in three this was strong and in six it was moderate. The only grade 11 infiltrating ductal carcinoma was in this last category; all the other heterogeneous staining tumours were grade 111 (Table 1).

Figure 1 shows examples of different types of staining patterns obtained using antibody CM-1: Panels A and B show samples T855 and T993 respectively both exhibiting strong intense nuclear staining throughout the malignant tissue, usually indicating the presence of high levels of altered p53 protein. Panel $\mathrm{C}$ shows an example of a tumour section exhibiting moderate staining (T894).

\section{Incidence of p53 somatic mutations in sporadic breast cancer}

DNA isolated from blood-tumour pairs from sporadic breast cancer patients was analyzed for the presence of p53 mutations. Only tumour sections exhibiting moderate to strong positive staining using the anti-p53 antibody CM-1, were used for this genetic analysis. We found only 3 (19\%) mutations in sporadic tumours from 16 breast cancer patients. The three mutations were all found in grade 111 infiltrating ductal carcinomas. The sequence data of the 3 mutations found are shown in Fig. 2. A mutation at codon 282 in exon 8 was found in tumour T894 (panel A) which exhibited scattered heterogeneous moderate staining. This mutation in conserved Box $\mathrm{V}$ resulted in an Arg-Gln amino-acid change (CGG-CAG). The mutation at codon 259 in exon 7 found in another tumour with heterogeneous moderate staining T1008 (panel B) lay just outside conserved Box IV but still within exon 7 of the p53 gene and caused the amino-acid change Asp-Arg (GACAGA). A mutation at codon 173 in exon 5 was found in tumour T855 (panel C) in which the majority of nuclei stained strongly with a homogeneous positive reaction. The mutation is in conserved Box III of the gene and results in a G-A transversion (GTGATG) causing a Val-Met amino-acid change. All point mutations altered the coding sequence and were present in exons 5 through 8. No mutation was found in T993 which exhibited similar strong nuclear staining to T855 (Table 1).

\section{Incidence of p53 germ-line mutations in familial breast cancer}

We analyzed the genomic DNA from eleven women with a positive family history of breast cancer by direct sequencing; but were unable to find constitutional p53 mutations in any of the affected individuals. Tumours from six of these patients were available for immunohistochemical staining. One of the tumours stained negatively and two cases showed strong homogeneous staining. In three cases the staining was heterogeneous, in one it was moderate and in two it was strong.

\section{Nasopharyngeal tumour samples}

Immunohistochemical staining was performed on eight nasopharyngeal samples using either the monoclonal antibodies pAB240 or pAb1801. There were four cases of positive staining using either antibody, three cases exhibited negative staining and one ambiguous case presented with abnormal histology. One biopsy was taken from a patient with multiple cancers including lung cancer. No alteration of the p53 DNA sequence in exons 5-9 in these biopsy specimens was observed. 
Table 1. Description of p53 mutations found in sporadic breast tumours

\begin{tabular}{|c|c|c|c|c|}
\hline Case & $\begin{array}{l}\text { Age at } \\
\text { Diagnosis }\end{array}$ & $\begin{array}{l}\text { p53 antibody } \\
\text { staining pattern } \\
\text { and intensity }\end{array}$ & $\begin{array}{l}\text { Codon } \\
\text { Mutation }\end{array}$ & $\begin{array}{l}\text { Pathology and } \\
\text { Tumour grading }\end{array}$ \\
\hline $\mathrm{T} 742$ & 28 & $\begin{array}{l}\text { Homogeneous } \\
+++\end{array}$ & & $\begin{array}{l}\text { Infiltrating Ductal } \\
111\end{array}$ \\
\hline $\mathrm{T} 855$ & 48 & $\begin{array}{l}\text { Homogeneous } \\
+++\end{array}$ & 173 & $\begin{array}{l}\text { Infiltrating Ductal } \\
111\end{array}$ \\
\hline T871 & 76 & $\begin{array}{l}\text { Homogeneous } \\
+++\end{array}$ & & $\begin{array}{l}\text { Infiltrating Ductal } \\
111\end{array}$ \\
\hline T913 & 63 & $\begin{array}{l}\text { Homogeneous } \\
+++\end{array}$ & & $\begin{array}{l}\text { Infiltrating Ductal } \\
111\end{array}$ \\
\hline T972 & 60 & $\begin{array}{l}\text { Homogeneous } \\
+++\end{array}$ & & $\begin{array}{l}\text { Infiltrating Ductal } \\
111\end{array}$ \\
\hline T993 & 50 & $\begin{array}{l}\text { Homogeneous } \\
+++\end{array}$ & & Infiltrating Lobular \\
\hline $\mathrm{T} 1003$ & 36 & $\begin{array}{l}\text { Homogeneous } \\
.++\end{array}$ & & $\begin{array}{l}\text { Infiltrating Ductal } \\
111\end{array}$ \\
\hline T879 & 60 & $\begin{array}{l}\text { Heterogeneous } \\
.+++\end{array}$ & & $\begin{array}{l}\text { Infiltrating Ductal } \\
111\end{array}$ \\
\hline T895 & 81 & $\begin{array}{l}\text { Heterogeneous } \\
+++\end{array}$ & & $\begin{array}{l}\text { Infiltrating Ductal } \\
111\end{array}$ \\
\hline T957 & 80 & $\begin{array}{l}\text { Heterogeneous } \\
++\end{array}$ & & $\begin{array}{l}\text { Infiltrating Ductal } \\
111\end{array}$ \\
\hline $\mathrm{T} 870$ & 69 & $\begin{array}{l}\text { Heterogeneous } \\
++\end{array}$ & & $\begin{array}{l}\text { Infiltrating Ductal } \\
111\end{array}$ \\
\hline T894 & 49 & $\begin{array}{l}\text { Heterogeneous } \\
++\end{array}$ & 282 & $\begin{array}{l}\text { Infiltrating Ductal } \\
111\end{array}$ \\
\hline T934 & 58 & $\begin{array}{l}\text { Heterogeneous } \\
++\end{array}$ & & $\begin{array}{l}\text { Infiltrating Ductal } \\
11\end{array}$ \\
\hline Т949 & 36 & $\begin{array}{l}\text { Heterogeneous } \\
++\end{array}$ & & $\begin{array}{l}\text { Infiltrating Ductal } \\
111\end{array}$ \\
\hline T1008 & 36 & $\begin{array}{l}\text { Heterogeneous } \\
++\end{array}$ & 259 & $\begin{array}{l}\text { Infiltrating Ductal } \\
111\end{array}$ \\
\hline T1009 & 64 & $\begin{array}{l}\text { Heterogeneous } \\
++\end{array}$ & & $\begin{array}{l}\text { Infiltrating Ductal } \\
111\end{array}$ \\
\hline
\end{tabular}

+++ Strong staining

++ Moderate staining 

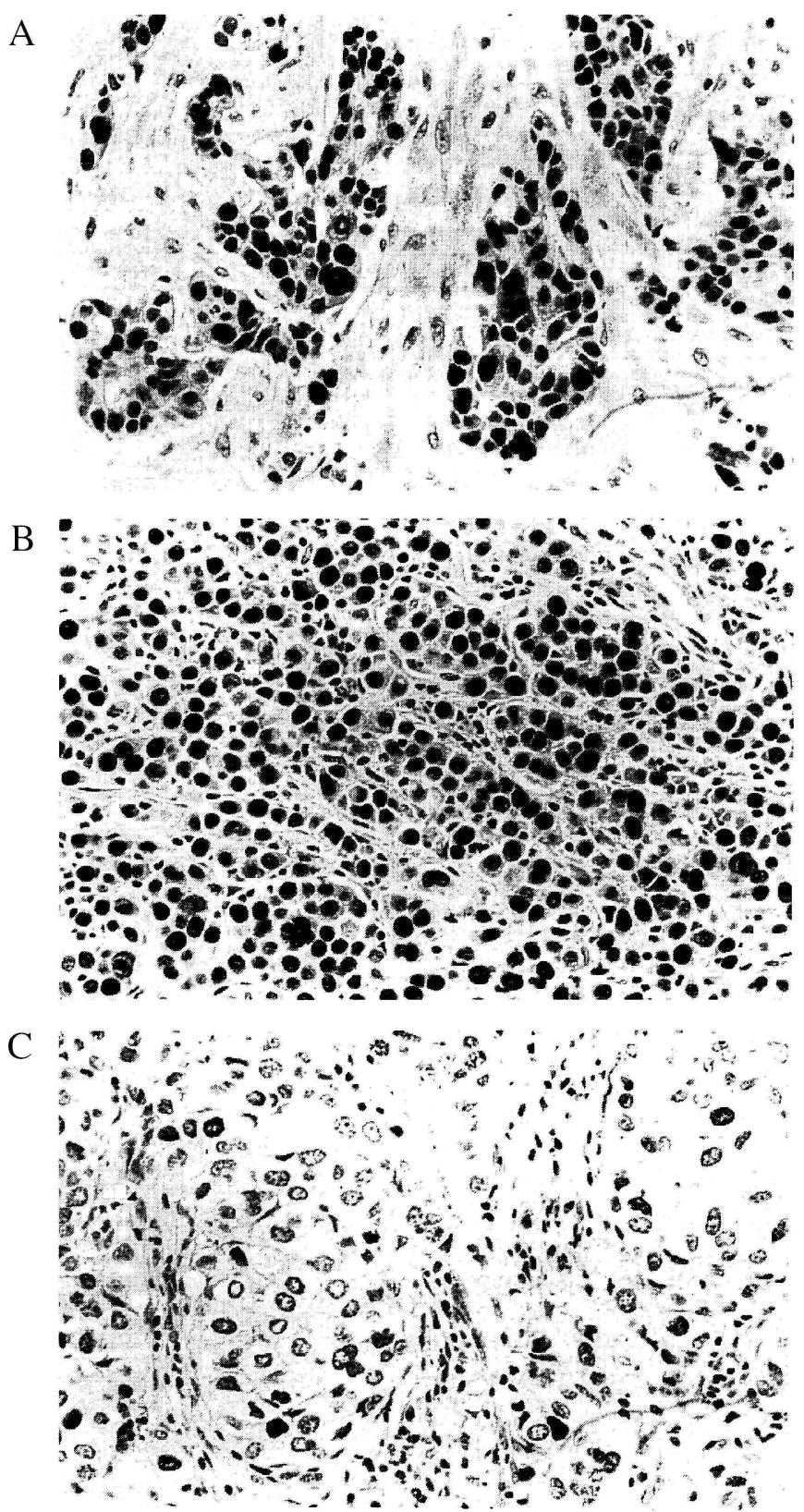

Figure 1. Panels A, B and C show p53 staining patterns detected with the antibody $\mathrm{CM}-1$ on primary breast tumour samples. Panel A: T855 shows strong nuclear staining and a mutation was detected at codon 173. Panel B: T993 also shows strong nuclear staining but no DNA mutation detected. Panel C: T894 shows heterogeneous patchy staining and mutation was detected at codon 282 . 
A

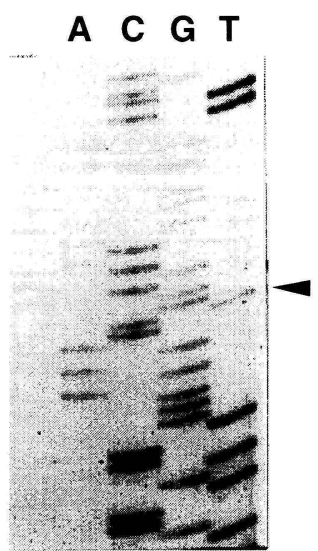

T894
B

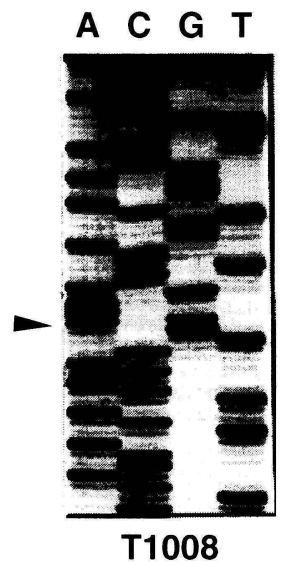

$\mathrm{C}$

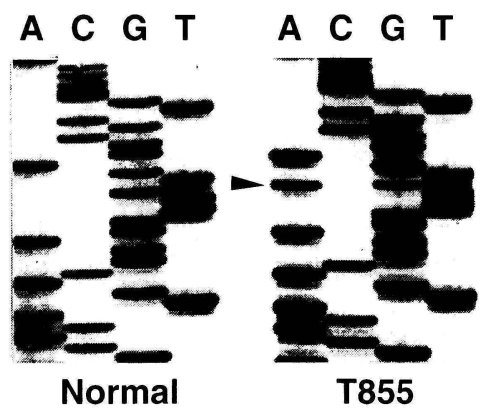

Figure 2. Position of p53 gene mutations for three breast cancer tumour samples. PCR and direct sequencing of exons 5-9 was performed as described in the text. Details of the exact codon alterations and amino-acid changes are also described in the text. (A). Mutation at codon 282 detected in tissue T894. (B). Mutation at codon 259 in tumour T1008. (C). Mutation at codon 173 in tumour T855, the sequence also shows the presence of the wild-type nucleotide at the same position.

\section{Melanoma samples}

None of the 5 dysplastic naevi available demonstrated any form of immunoreactivity with antibody CM-1. Of the 14 primary melanoma tumours, 13 were negative for $\mathrm{p} 53$ expression and one showed cytoplasmic staining. Among the 9 secondary melanomas, 3 exhibited positive although scattered staining, 2 showed cytoplasmic staining and 4 samples were negative for p53 protein. A positive breast tumour sample was used as control. Nine melanoma tissue /blood pairs were analyzed for the presence of p53 mutations by direct sequencing. DNA from one tissue /blood pair was obtained from a patient with a strong family history of melanoma. No DNA mutations in the p53 gene were detected in any of the samples analyzed.

\section{DISCUSSION}

In this paper we have attempted to perform case by case correlative studies between p53 immunohistochemical positivity and a concordant mutation within the p53 gene. Since $98 \%$ of p53 base substitution mutations in human cancer fall within exons 4-9 (Hollstein et al., 1991), we have confined our analysis to this region of the gene. Tumour mutations may, however, occur outside this region although reports are rare. Our results confirm recent findings in the long standing but false assumption that p53 immunohistochemical positivity is synonymous with over expression of the mutant gene (WynfordThomas, 1992).

In this study we have found that only $19 \%$ of breast tumours selected on the basis of positive p53 immunostaining contained a mutation in the p53 gene, a finding similar to 
that by Mazars et al. (1992) who studied the frequency of p53 DNA mutations in 96 primary breast cancer patients although immunostaining was not performed. Both these data sets would tend to confirm the findings described by Coles et al. (1992) who collated their own data from 136 breast cancer patients and those of others and found serious discrepancies in the estimates between analysis at the DNA level and analysis at the protein level. In a study using antibody staining and SSCP analysis of the tumour DNA only 2 samples out of 81 showed both positive staining and a DNA mutation (Dunn et al., 1993). Therefore, it follows that the p53 protein can be stabilized by mechanisms other than a mutation within the gene. One such mechanism has been proposed by Moll et al. (1992) who suggested that some breast cancers may sequester the normally nuclear p53 protein in the cytoplasm thereby inactivating its tumour suppressor function. However, whatever the precise mechanisms may be in mammary carcinomas, positive staining in the majority of tumour cells is an indication of poor prognosis (Barnes et al., 1993). It is of interest to note that the three mutations we identified were from women less than 50 years of age. No mutations were found in breast cancers from women over the age of 50 in this series.

From our study of eleven breast cancer families we found no apparent constitutional p53 mutations. The disparity between p53 immunopositivity and mutation is again emphasised by the fact that tumour tissue available from six of these women exhibited moderate to intense strong staining using the antibody CM-1. Warren et al. (1992) also failed to detect germ-line p53 mutations through exons 5-9 in 25 families with strong histories of breast carcinoma. Together these results indicate that familial breast cancer does not usually arise from mutations within the p53 gene. In a separate study of twelve women who had breast cancer but had no strong family history of inherited cancer we found one patient with a 533 point mutation at codon 244 resulting in a G-A transversion leading to a methionine to isoleucine amino acid substitution. (data not shown). We have also described previously a mother and daughter with breast cancer who both have high concentration of p53 protein in normal epithelial tissue but no mutation within the p53 gene (Barnes et al., 1992). This new phenotype of inherited cancer susceptibility is distinct from germ-line mutations found in Li-Fraumeni families.

Stabilisation of p53 occurs as a response to UV induced damage seen in normal cells. A similar mechanism may explain the unusually high level (85\%) of p53 over-expression by immunohistochemistry observed in primary and malignant melanomas (Stretch et al., 1991). However, the frequency of p53 gene mutations was not analyzed by these authors so a direct correlation could not be drawn. In contrast we found overexpression of p53 protein in only $25 \%$ of our primary or metastatic melanoma tumours. The lack of staining in dysplastic naevi is in agreement. with the previous study. A recent paper by Lassam et al., (1993), also report that $\mathrm{p} 53$ protein as detected by the monoclonal antibodies DO7 and 1801, is not over expressed in benign or dysplastic naevi. In the same study, of the primary melanomas investigated, only $5 \%$ demonstrated nuclear staining, a result similar to our findings. However, $70 \%$ of metastatic melanomas displayed positive staining, in contrast with our data. Taken together however, these observations suggest that p53 overexpression occurs at a late stage in the progression of malignant melanoma and that other gene products are involved in the initiation of melanoma. The reasons for the discrepancies between the levels of p53 expression described by Stretch et al. (85\%) and Lassam et al. $(5 \%)$ and our own data in primary melanomas is unclear. However, considerable variations in p53 mutations have been reported in other skin cancers (Moles et al., 1993; 
Waterhouse et al., 1982). The sites and levels of exposure to UV light appear to be crucial factors in the genesis of many skin related cancers. In our samples no mutations were observed in exons 4-9 of the p53 gene. One blood-tumour pair was obtained from a family member with a strong history of dysplastic naevus syndrome and melanoma. It would appear unlikely that a mutation in the p53 gene on $17 \mathrm{p}$ plays a major role in the progression of this disease.

Similarly we did not detect any point mutations in any of the 8 NPC clinical specimens analyzed. In agreement with recent data (Spruck et al.,1992; Sun et al., 1992; Effert et al., 1992), we conclude that mutational alterations within the p53 gene are not a critical event in the initial stages of nasopharyngeal carcinogenesis. The Epstein-Barr Virus (EBV) is consistently detected in NPC and it may be that some aspect of p53 function is modified by interactions with EBV (Effert et al., 1992 ), resulting in the absence of p53 mutations even though 53 protein can be detected immunohistochemically. Again our results from this data set emphasise the danger in assuming that positive staining is an indication of an underlying mutation since all sections selected for genetic analysis exhibited moderate to strong staining.

A major criticism of studies to identify DNA mutations in tumour tissues has been in the use of direct sequencing to identify DNA mutations. It has been suggested that this technique is less sensitive than analysis for single stranded confirmation polymorphisms. To reduce the likelihood, DNA was extracted from the most cellular part of the tumour and an adjacent piece of tissue was taken for haematoxylin and eosin staining to confirm that the sample was adequate and representative of the whole tumour.

It is now becoming clear that $\mathrm{p} 53$ protein acts as a tumour suppressor through a distinct pathway involving other components. Inactivation or amplification of these other factors may then be as effective as p53 mutation in mediating p53 function. For example, the MDM2 protein binds to p53 and subsequently blocks its ability to act as a transcription factor (Momand et al., 1992). In sarcomas with MDM2 amplification, p53 mutations are rare, whereas such mutations are common in other sarcomas (Oliner et al., 1992). Interestingly, two recent papers (Lowe et al. 1993; Clarke et al., 1993) have demonstrated the role of p53 in the induction of apoptosis. Inactivation of p53 by radiation leads to an increase in p53 levels, inactivation of the p53 pathway and subsequent survival of cells exposed to mutagens. Genes that bind to and are stimulated by p53 as well as interacting transcription factors will now be important to identify in order to elucidate not only their role but also that of p53 in human malignancies.

\section{REFERENCES}

Barnes, D.M., Hanby, A.M., Gillett, C.E., Mohammed, S., Hodgson, S., Bobrow, L.G., Leigh, I.M., Purkis, T., MacGeoch, C., Spurr, N.K., Bartek, J., Vojtesek, B., Picksley, S.M., and Lane, D.P.(1992). Abnormal expression of wild type p53 protein in normal cells of a cancer family patient. Lancet, 340, 259-263.

Barnes, D.M., Dublin, E.A., Fisher, C.J., Levison, D.A., Millis, R.R.(1993). Immunohistochemical detection of p53 protein in mammary carcinoma: An important new independent indicator of prognosis? Human Pathology, 24, 469-476.

Bartek, J., Iggo, R., Gannon, J. and Lane, B P. Genetic and immunohistochemical analysis of mutant p53 in human breast cancer cell lines.(1990). Oncogene 5; 893-899. 
Bartek, J., Bartkova, J., Vojtesek, B., Staskova, Z., Lukas, J., Rejthar, A., Kovarik, J., Midgley. C.A., Gannon, J.V., Lane, D.P.(1991). Aberrant expression of the p53 oncogene is a common feature of a wide spectrum of human malignancies. Oncogene, 6: 1699-1703.

Bloom, H.J.C., and Richardson,W.W. (1957). Histological grading and prognosis in breast cancer. Br. J. Cancer, 11, 359.

Brash, D.E., Rudolph, J.A., Simon, J.A, Lin, A., McKenna, G.J., Baden, H.P., Halperin, A.J and Ponten, J. (1991). A role for sunlight in skin cancer: UV-induced p53 mutations in squamous cell carcinoma. Proc. Natl. Acad. Sci. USA, 88, 10124-10128.

Bressac, B., Kew, M., Wands, J., and Ozturk, M. (1991). Selective G to T mutations of p53 gene in hepatocellular carcinoma from Southern Africa. Nature (Lond), 350, 429-431.

Clarke, A.R., Purdie, C.A., Harrison, D.J., Morris, R.G., Bird, C.C., Hooper, M.L., and Wyllie, A.H. (1993). Thymocyte apoptosis induced by p53-dependent and independent pathways. Nature (Lond), 362, 849-852.

Coles, C., Condie, A., Chetty, U., Steel, C.M., Evans H.J., and Prosser, J. (1992). p53 mutations in breast cancer. Cancer Research, 52, 5291-5298.

Davidoff, A.M., Humphrey, P.A., Iglehart, J.D., Marks, J.R.(1991). Genetic basis for p53 overexpression in human breast cancer. Proc. Natl. Acad. Sci., 88, 5006-5010.

Dunn,J M., Hastrich, D J., Newcomb, P., Webb, J C J., Maitland, N J. and Farndon, J R. (1993). Correlation between p53 mutations and antibody staining in breast carcinoma. Br. J. Surg. 80, $1410-1412$.

Effert, P., McCoy, R., Abdel-Hamid, M., Flynn, K., Zhang, Q., Busson, P., Tursz, T., Liu,E. and Raab-Traub, N. (1992). Alterations of the p53 gene in nasopharyngeal carcinoma. Journal of Virology, 66, 3768-3775,.

Farmer, G., Bargonetti, J., Zhu, H., Friedman, P., Prywes, R., and Prives, C. (1992). Wild-type p53 activates transcription in vitro. Nature (Lond), 358, 83-86.

Fisher, C J., Gillett, C E., Barnes, D M. and Millis, R R.(1994). Problems in immunohistochemical staining: the effect of foxation and variation in the methods of evaluation. Br. J. Cancer, 69, 2631.

Hall, P.A., McKee, P.H., Menage, H.du P., Dover, R. and Lane. D.P. (1993). High levels of p53 protein in UV-irradiated normal human skin. Oncogene, 8, 203-207.

Hollstein, M., Sidransky, D., Vogelstein, B., Harris, C.C. (1991). p53 mutations in human cancers. Science, 253, 49-53.

Johns Jr, M.B., and Pauls-Thomas, J.E. (1989). Isolation of DNA from whole blood using sodium perchlorate. Anal. Biochem., 180, 276-278.

Lane, D.P.(1992). p53, guardian of the genome. Nature (Lond), 358, 15-16.

Lassam, N.J., From, L., Kahn, H.J. (1993). Overexpression of p53 is a late event in the development of malignant melanoma. Cancer Research, 53, 2235-2238.

Levine, A.J., Momand, J and Finlay, C.A. (1991). The p53 tumour suppressor gene. Nature (Lond),351, 453-456.

Lowe, S., Schmitt, E. M., Smith, S.W., Osborne, B.A. and Jacks, T.(1993). p53 is required for radiation induced apoptosis in mouse thymocytes. Nature (Lond), 362, 847-849.

MacGeoch, C., Kennedy, S., and Spurr, N. K.(1991). Strategies for amplification of human p53 gene sequences. Technique, 3, 179-182.

Maltzman, W., Czyzyk, L. (1984). UV irradiation stimulates levels of p53 cellular tumour antigen in non-transformed mouse cells. Mol. Cell. Biol., 4, 1689-1694.

Mazars, R., Spinardi, L,. BenCheikh, M., Simony-Lafontaine, J., Jeanteur, P., and Theillet, C. (1992). p53 mutations occur in aggressive breast cancer. Cancer Research, 52, 3918-3923.

Midgley, C.A., Fisher, C.J., Bartek, J., Vojtesek, B., Lane, D.P., and Barnes, D.M. (1992). Analysis of p53 expression in human tumours: an antibody raised against human $\mathrm{p} 53$ expressed in E.coli. J. Cell Science, 101, 183-189. 
Momand,J., Zambetti, G.P., Olson, D.C., George, D.and Levine, A.J. (1992). The mdm-2 oncogene product forms a complex with the $\mathrm{p} 53$ protein and inhibits $\mathrm{p} 53$-mediated transactivation. Cell, 69, 1237-1245.

Moll, U.T., Riou, G, and Levine, A.J. (1992). Two distinct mechanisms alter p53 in breast cancer: Mutation and nuclear exclusion. Proc. Natl. Acad. Sci., 89, 7262-7266.

Nigro, J.M., Baker, S.J., Preisinger, A.C., Jessup, J.M., Hostetter, R., Cleary, K., Bigner, S.H., Davidson, N., Baylin, S., Devilee, P., Glover, T., Collins, F.S., Weston, A., Modali, R., Harris,C.C., Vogelstein, B. (1989). Mutations in the p53 gene occur in diverse tumour types. Nature (Lond), 342, 705-708.

Oliner, J.D., Kinzler, K.W., Meltzer, P.S., George, D.L., and Vogelstein, B. (1992). Amplification of a gene encoding a p53-associated protein in human sarcomas. Nature (Lond), 358, 80-83.

Osborne, R.J., Merlo, G.R., Mitsudomi, T., Venesio, T., Liscia, D.S., Cappa, A.P.M., Chiba, I., Takahashi, T., Nau, M.M., Callahan, R, and Minna, J.D. (1991). Mutations in the p53 gene in primary human breast cancers. Cancer Research, 51, 6194-6198.

Sambrook, J., Fritsch, E.F., Maniatis, T. (1989). Molecular Cloning, A Laboratory Manual. Second Edition, Cold Spring Harbour Laboratory Press.

Sidransky, D., Tokino, T., Helzlsouer, K., Zehnbauer, B., Rausch, G., Shelton, B., Prestigiacomo, L., Vogelstein, B., Davidson, N. (1992). Inherited p53 gene mutations in breast cancer. Cancer Res., 52, 2984-2986.

Soussi, T., Caron de Fromentel, C., and May, P. (1991). Structural aspects of the p53 protein in relation to gene evolution. Oncogene, 5, 49-53.

Spruck, C.H.111., Tsai, Y.C., Huang, D.P., Yang, A.S., Rideout, W.M.111., Gonzalez-Zulueta, M., Choi, P., Lo, K-W., Yu, M.C., and Jones, P.A. (1992). Absence of p53 gene mutations in primary nasopharyngeal carcinomas. Cancer Research, 52: 4787-4790.

Stretch, J.R., Gatter, K.C., Ralfkiaer, E., Lane, D.P., and Harris, A.L. (1991). Expression of p53 in melanoma. Cancer Research, 51, 5976-5979.

Sun, Y., Hegamyer, G., Cheng, Y-J., Hildesheim, A., Chen, J-Y., Chen, I-H., Cao, Y., Yao, K-T., and Colburn, N.H.(1992). An infrequent point mutation of the $\mathrm{p} 53$ gene in human nasopharyngeal carcinoma. Proc. Natl. Acad. Sci., 89, 6516-6520.

Varley, J.M., Brammar,W.J., Lane, D.P., Swallow, J.E., Dolan, C., Walker, R.A. (1991). Loss of chromosome $17 \mathrm{p} 13$ sequences and mutation of p53 in human breast carcinomas. Oncogene, 6 : 413-421.

Warren, W., Eeles, R.A., Ponder, B.A.J., Easton, D.F., Averill, D., Ponder, M.A., Anderson, K., Evans, A.M., DeMars, R., Love, R., Dundas, S., Stratton, M.R., Trowbridge, P., Cooper, C.S. and Peto, J. (1992). No evidence for germ-line mutations in exons 5-9 of the p53 gene in 25 breast cancer families. Oncogene, 7, 1043-1046.

Waterhouse, J., Muir, C.S., Shanmugaratnam, K., Powell, J. (1982). Cancer incidence in five continents, Vol IV. Lyon: IARC Scientific Publication, No. 42.

World Health Organisation, (1982), Geneve, Switzerland. Histological typing of breast tumours. Tumori, 68: 181-198.

Wynford-Thomas, D. (1992). p53 in tumour pathology: can we trust immunocytochemistry? J. of Pathology, 166: 329-330. 


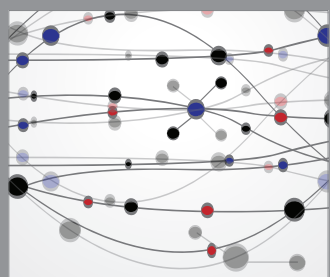

The Scientific World Journal
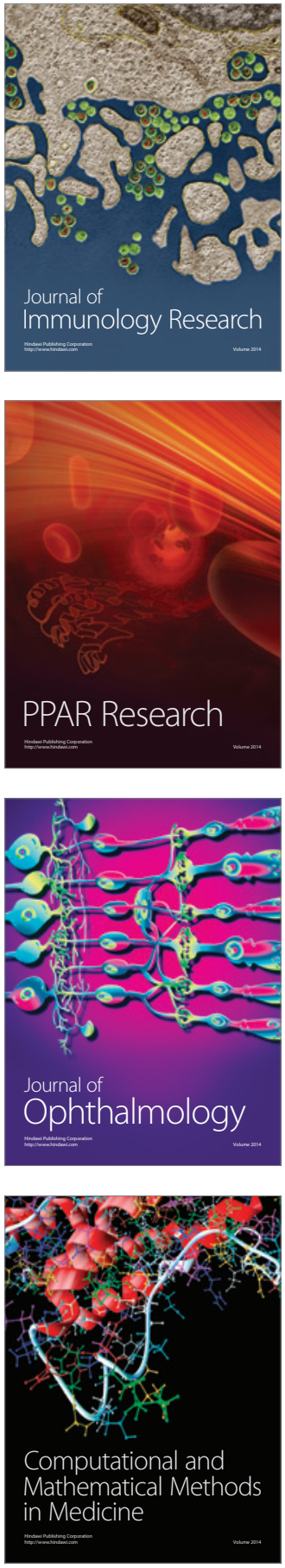

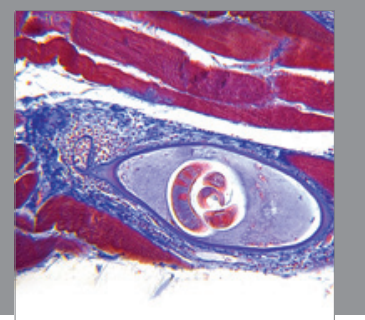

Gastroenterology

Research and Practice
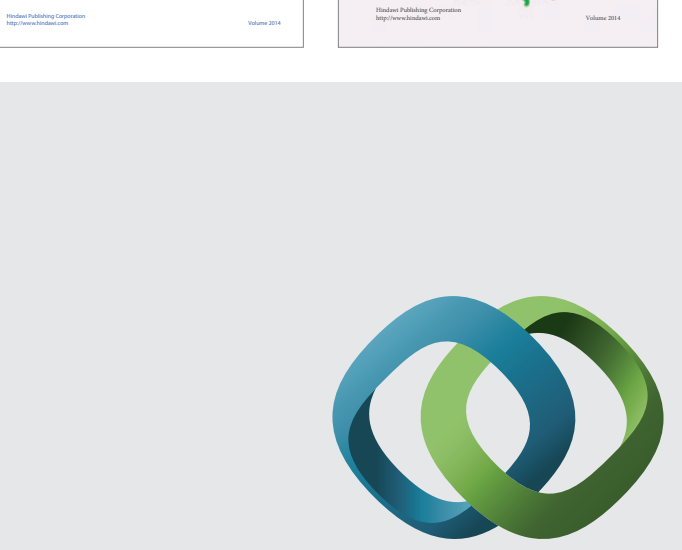

\section{Hindawi}

Submit your manuscripts at

http://www.hindawi.com
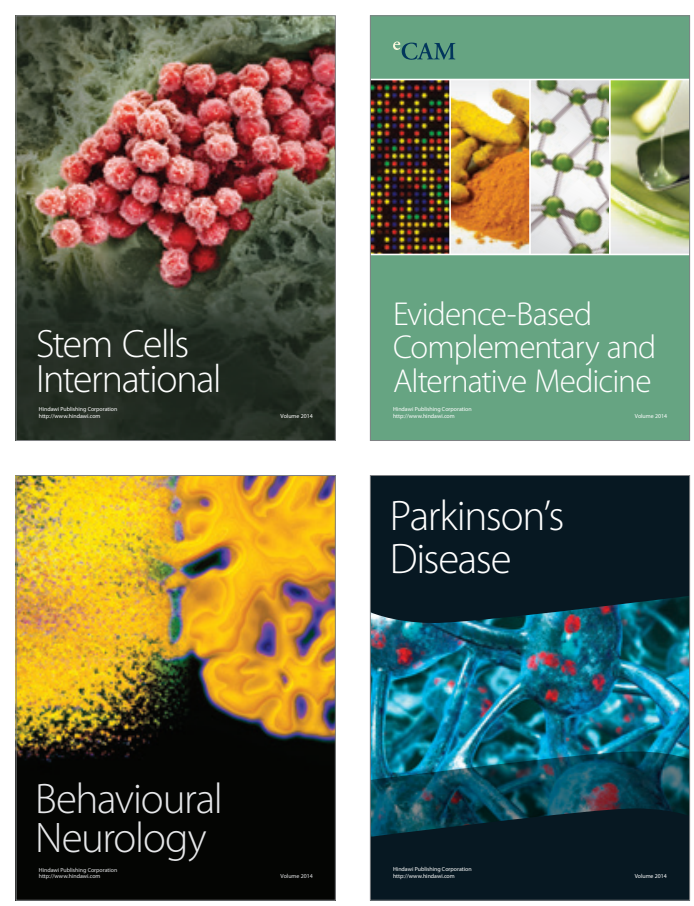

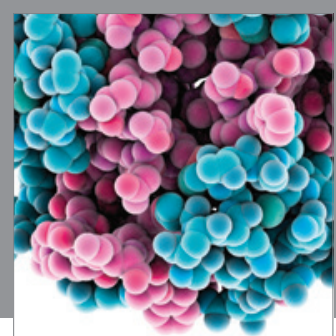

Journal of
Diabetes Research

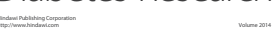

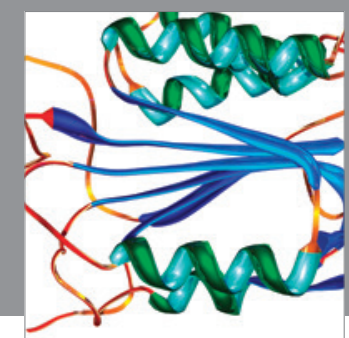

Disease Markers
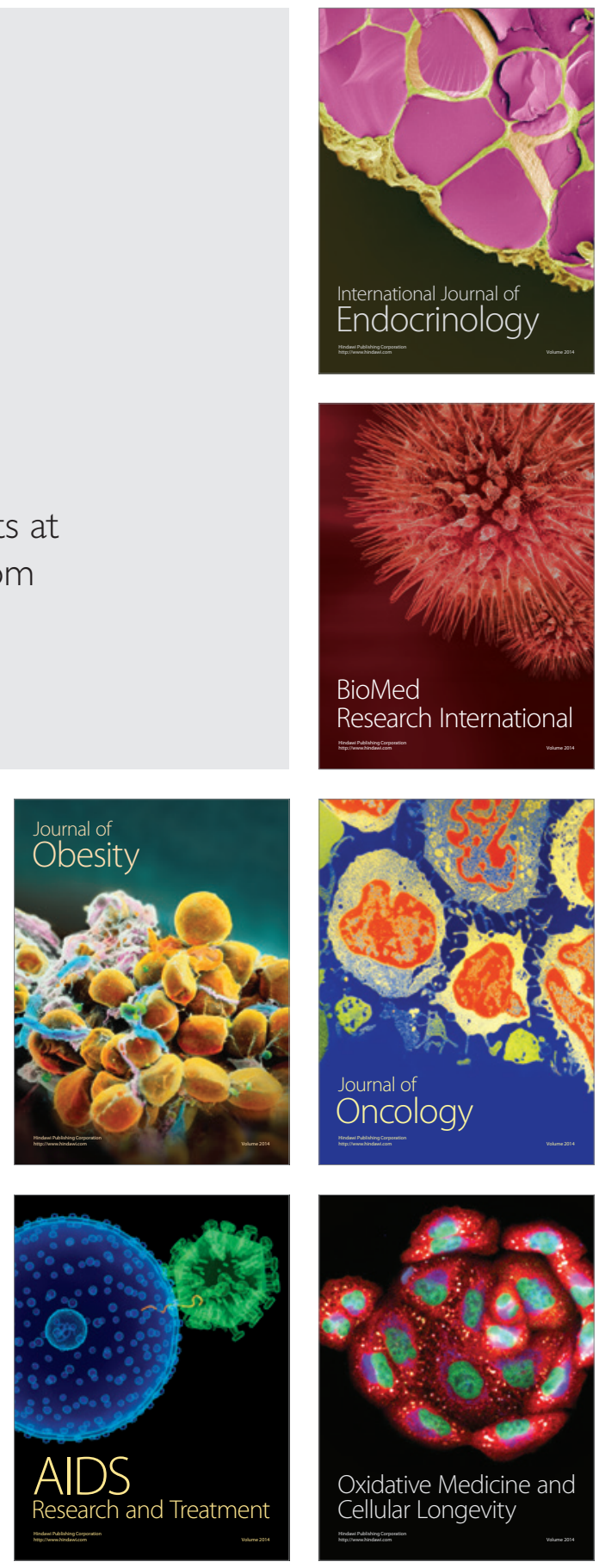